Article

\title{
Synthesis and Characterization of Nitrogen-doped Carbon Nanotubes Derived from g- $\mathrm{C}_{3} \mathrm{~N}_{4}$
}

\author{
Klaudia Maślana $\mathbb{D}$, Ryszard J. Kaleńczuk, Beata Zielińska * $\mathbb{D}$ and Ewa Mijowska $\mathbb{D}$ \\ Nanomaterials Physicochemistry Department, Faculty of Chemical Technology and Engineering, \\ West Pomeranian University of Technology, Piastow Av. 45, 70-311 Szczecin, Poland; \\ mk30511@zut.edu.pl (K.M.); rk@zut.edu.pl (R.J.K.); emijowska@zut.edu.pl (E.M.) \\ * Correspondence: bzielinska@zut.edu.pl
}

Received: 4 February 2020; Accepted: 13 March 2020; Published: 17 March 2020

check for updates

\begin{abstract}
Here, nitrogen-doped carbon nanotubes (CNT-N) were synthesized using exfoliated graphitic carbon nitride functionalized with nickel oxides (ex-g- $\mathrm{C}_{3} \mathrm{~N}_{4}-\mathrm{NixO} \mathrm{O}_{\mathrm{y}}$ ). CNT-N were produced at $900{ }^{\circ} \mathrm{C}$ in two steps: (1) ex-g- $\mathrm{C}_{3} \mathrm{~N}_{4}-\mathrm{Ni}_{\mathrm{x}} \mathrm{O}_{\mathrm{y}}$ reduction with hydrogen and (2) ethylene assisted chemical vapor deposition (CVD). The detailed characterization of the produced materials was performed via atomic force microscopy (AFM), transmission electron microscopy (TEM), Raman spectroscopy, X-ray diffraction (XRD) and thermogravimetric analysis (TGA). The possible mechanism of nanotubes formation is also proposed.
\end{abstract}

Keywords: graphitic carbon nitride; nickel oxides; nitrogen-doped carbon nanotubes; CVD process

\section{Introduction}

The discovery of diverse nanocarbon allotropes and its nanocomposites has inspired scientists for a range of potential applications. Here, for many years, carbon nanotubes have received huge scientific interest due to their unusual features, such as unique atomic structure, high surface, remarkable mechanical, electrical and thermal properties. The modification of carbon nanotubes (CNTs) by attaching functional groups to the surface and doping with heteroatoms or metal/metal oxide nanoparticles is the most promising strategy with respect to their potential application. For example, the doping of CNTs with nitrogen makes defects that alter the chemical properties of CNTs and creates a path to applications.

It is well known that the properties of solid materials are attributed to surface morphology. Thus, materials have to be modified prior to applications to improve their specific properties [1-6]. The surface modification of materials can be done by two main paths: (i) by attaching functional groups [7-9] and (ii) by introducing heteroatoms (e.g., nitrogen, boron, phosphorus, sulfur) in the molecular structure of materials [10-12]. From all of the heteroatoms, nitrogen is the one of the most investigated because it is sustainable for carbon replacing due to the fact that $\mathrm{N}$ and $\mathrm{C}$ atoms possess similar atomic radius and are chemically relatively easy to replace $[13,14]$. Furthermore, nitrogen possesses one electron more than carbon, which is desirable for electrochemical reactions such as the oxygen evolution reaction (OER) [15]. Nitrogen doping may also affect electron conductivity, electron-donor properties and chemical stability of the host material due to the modification of the electronic and crystal structure [16]. Moreover, the incorporation of nitrogen into the structure of molecules modifies their geometric properties, which results in an increase in the number of active sites and improves the interaction between the carbon structure and absorbate [17].

Nitrogen-doped carbon nanotubes have found application in many various fields, such as electrochemistry, energy storage, $\mathrm{CO}_{2}$ adsorption, Li-ion batteries and others [18-22]. In this context, Wu et al. [23] demonstrated that N-doped CNT enhanced the energy storage capacity and improved 
properties of produced batteries. Ariharan et al. [17] revealed that nitrogen-doped carbon nanotubes showed a higher hydrogen storage capacity of $\sim 2 \mathrm{wt} \%$ total adsorption, which is higher compared to other nitrogen-enriched carbon nanostructures. Another team, Liu et al. [24], reported that nitrogen-doped carbon nanotubes and graphitic carbon nitride nanocomposites exhibit an excellent ability to photocatalytic hydrogen evolution rate of $1208 \mu \mathrm{mol} \mathrm{g}^{-1} \mathrm{~h}^{-1}$. In addition to applications related to electrochemistry, nitrogen-doped carbon nanotubes have been used for production sensors [25] or organic pollutant removal [26].

Various preparation methods have been employed to obtain nitrogen-doped carbon nanotubes. The most widely used method of preparing nitrogen-doped carbon nanotubes is chemical vapor deposition $[27,28]$. One of the most significant advantages of this method is its simplicity, which is the reason for its widespread use. However, N-doped CNT are obtained by other methods as well, such as in situ synthesis and post nitridation treatment [29], catalytic pyrolysis of dimethylformamide [30] and plasma treatment [31].

It is well known that ethylene plays the most important role during the chemical vapor deposition process. It is the main source of carbon, which in this process is necessary for the growth of carbon nanotubes. During the production of single-walled carbon nanotubes and multi-walled carbon nanotubes, hydrocarbons such as ethylene, acetylene, benzene or methane have been decomposed into single carbon atoms or linear dimers/trimers. This step takes place on the surface of metallic catalysts and results in $\mathrm{CNT}$ growth $[32,33]$. The process usually takes place in the temperature range of $500-1000{ }^{\circ} \mathrm{C}[34]$.

In this work, we present a novel route to prepare nitrogen-doped carbon nanotubes (CNT-N) from graphitic carbon nitride functionalized with nickel oxides (ex-g- $\mathrm{C}_{3} \mathrm{~N}_{4}-\mathrm{Ni}_{\mathrm{x}} \mathrm{O}_{\mathrm{y}}$ ) by the chemical vapor deposition (CVD) method. We also propose the mechanism of reshaping of the flake-like structure into the tubular form.

\section{Details Experimental}

\subsection{Materials and Procedures}

Melamine $\left(\mathrm{C}_{3} \mathrm{H}_{6} \mathrm{~N}_{6}, 99.0 \%\right)$ and nickel (II) acetate tetrahydrate $\left(\mathrm{Ni}\left(\mathrm{OCOCH}_{3}\right)_{2} \cdot 4 \mathrm{H}_{2} \mathrm{O}, \geq 99.0 \%\right)$ were purchased from Sigma Aldrich (St. Louis, MI, USA).

\subsubsection{Synthesis of Exfoliated Graphitic Carbon Nitride}

Bulk graphitic carbon nitride $\left(\mathrm{g}-\mathrm{C}_{3} \mathrm{~N}_{4}\right)$ was synthesized via thermal polycondensation of melamine. The process was carried out in muffle furnace at $550{ }^{\circ} \mathrm{C}$ for $2 \mathrm{~h}$ with a heating rate of $2{ }^{\circ} \mathrm{C} / \mathrm{min}$ in air atmosphere. Next, the obtained yellow product was exfoliated by sonication using Tip-ultra-sonicator ( $500 \mathrm{~W}$, Sonics VC505, Sonics \& Materials Inc., Newtown, USA). Here, a certain amount of the bulk $\mathrm{g}-\mathrm{C}_{3} \mathrm{~N}_{4}$ was mixed with isopropyl alcohol and sonicated for $24 \mathrm{~h}$. The final powdered product was obtained by evaporation of the solvent at $50{ }^{\circ} \mathrm{C}$. The exfoliated sample was denoted as ex-g- $\mathrm{C}_{3} \mathrm{~N}_{4}$.

\subsubsection{Synthesis of Functionalized Exfoliated Graphitic Carbon Nitride with Nickel Oxides}

In a typical synthesis of the procedure, ex-g- $\mathrm{C}_{3} \mathrm{~N}_{4}$ and $\mathrm{Ni}\left(\mathrm{OCOCH}_{3}\right)_{2} \cdot 4 \mathrm{H}_{2} \mathrm{O}$ in a weight ratio of 1:1 were mixed in isopropyl alcohol by sonication for $3 \mathrm{~h}$. Then, the obtained dispersion was stirred until the solvent evaporated. Finally, the product was annealed at $440^{\circ} \mathrm{C}$ for $10 \mathrm{~min}$. with a heating rate of $6^{\circ} \mathrm{C} / \mathrm{min}$ in a vacuum.

\subsubsection{Synthesis of Nitrogen-doped Carbon Nanotubes}

Exfoliated graphitic carbon nitride functionalized with nickel oxides (ex-g- $\mathrm{C}_{3} \mathrm{~N}_{4}-\mathrm{Ni}_{\mathrm{x}} \mathrm{O}_{\mathrm{y}}$ ) was placed in the ceramic boat and introduced into the tubular furnace. The furnace was heated under flowing nitrogen up to $900^{\circ} \mathrm{C}$. When the temperature was reached, hydrogen was introduced $(100 \mathrm{sccm})$ for $3 \mathrm{~h}$. Afterward, the hydrogen supply was cut off and ethylene was introduced to the furnace for 
$10 \mathrm{~min}$. Subsequently, the furnace was cooled down to room temperature. The as-obtained product was denoted as CNT-N.

\subsection{Characterization}

The morphology of the obtained samples was investigated by transmission electron microscopy with energy dispersive X-ray (EDX) spectroscopy (Tecnai F20-based at $200 \mathrm{kV}$ accelerating voltage, Thermo Fisher Scientific, Waltham, MA, USA) and scanning electron microscopy (TESCAN, VEGA 3, acquired in the $30 \mathrm{kV}$ acceleration voltage, TESCAN, Brno, Czech Republic). Selected area electron diffraction (SAED) patterns were obtained using TEM microscope (Thermo Fisher Scientific, Waltham, MA, USA). The AFM study was performed using an atomic force microscope (Nanoscope V Multimode 8, Bruker AXS, Mannheim, Germany). X-ray diffraction (XRD) patterns were carried out using an Empyrean (Malvern Panalytical, Malvern, UK) diffractometer using $\mathrm{CuK} \alpha$ radiation. Thermogravimetric analysis was carried out using TA-Q600 SDT TA Instrument (TA Instrument, New Castle, DE, USA) under the air and argon atmosphere at ramping rate of $10^{\circ} \mathrm{C} / \mathrm{min}$ from room temperature to $900^{\circ} \mathrm{C}$. Raman spectra were determined on inVia Raman Microscope (RENISHAW, New Mills Wotton-under-Edge, UK) with an excitation wavelength of $785 \mathrm{~nm}$.

\section{Results and Discussion}

\subsection{Microscopic Analysis}

The morphologies of $\mathrm{g}-\mathrm{C}_{3} \mathrm{~N}_{4}$, ex-g- $\mathrm{C}_{3} \mathrm{~N}_{4}$ and ex-g- $\mathrm{C}_{3} \mathrm{~N}_{4}-\mathrm{Ni}_{\mathrm{x}} \mathrm{O}_{\mathrm{y}}$ were studied by transmission electron microscopy. The TEM images of the samples are presented in Figure 1. TEM images of g- $\mathrm{C}_{3} \mathrm{~N}_{4}$ and ex-g- $\mathrm{C}_{3} \mathrm{~N}_{4}$ (Figure 1A,B) show a visible difference in the thickness of these two samples. Figure $1 \mathrm{C}$ and $\mathrm{D}$ exhibit that $\mathrm{Ni}_{\mathrm{x}} \mathrm{O}_{\mathrm{y}}$ nanoparticles were successfully deposited on the flakes of ex-g- $\mathrm{C}_{3} \mathrm{~N}_{4}$ (ex-g- $\mathrm{C}_{3} \mathrm{~N}_{4}-\mathrm{Ni}_{\mathrm{x}} \mathrm{O}_{\mathrm{y}}$ ). The average diameter of $\mathrm{Ni}_{\mathrm{x}} \mathrm{O}_{\mathrm{y}}$ particles is $\sim 32 \mathrm{~nm}$.

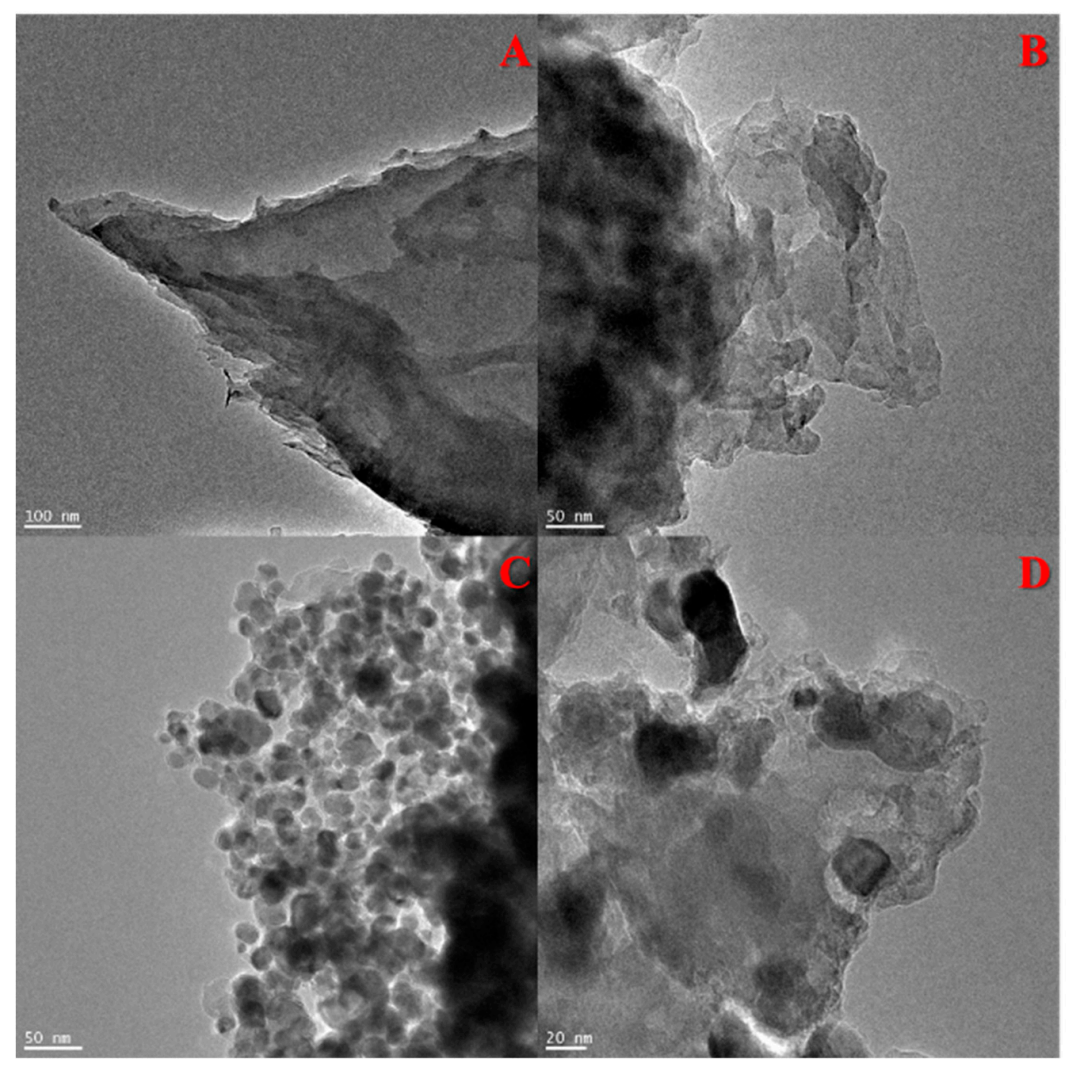

Figure 1. Transmission electron microscopy (TEM) images of (A) g- $\mathrm{C}_{3} \mathrm{~N}_{4},(\mathrm{~B})$ ex-g- $\mathrm{C}_{3} \mathrm{~N}_{4}$ and (C,D) ex-g- $\mathrm{C}_{3} \mathrm{~N}_{4}-\mathrm{Ni}_{\mathrm{x}} \mathrm{O}_{\mathrm{y}}$. 
Additionally, the topography of the exfoliated $\mathrm{g}-\mathrm{C}_{3} \mathrm{~N}_{4}$ was also examined via atomic force microscopy (Figure 2). The obtained data indicate that the thickness of ex-g- $\mathrm{C}_{3} \mathrm{~N}_{4}$ is $\sim 4-5 \mathrm{~nm}$, which means that this sample is composed of $\sim 10-13$ layers. According to the fact that bulk graphitic carbon nitride is composed of $\sim 100-170$ layers, we can conclude that the exfoliation step was efficient. Based on AFM images, the number of ex-g- $\mathrm{C}_{3} \mathrm{~N}_{4}$ layers is reduced by more than 30 times in comparison to the pristine $\mathrm{g}-\mathrm{C}_{3} \mathrm{~N}_{4}$, which is supported by TEM.

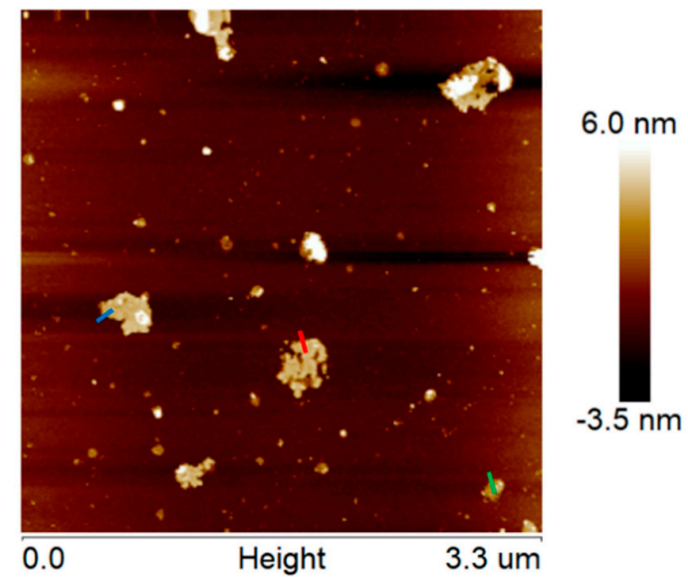

(A)

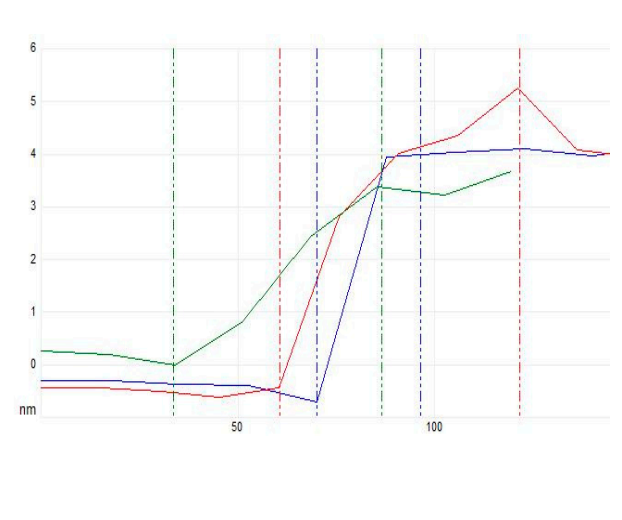

(B)

Figure 2. AFM images of ex-g- $\mathrm{C}_{3} \mathrm{~N}_{4}(\mathrm{~A})$ and corresponding high profile (B).

Figure 3 shows SEM images of $g-\mathrm{C}_{3} \mathrm{~N}_{4}$, ex-g- $\mathrm{C}_{3} \mathrm{~N}_{4}$ and the sample produced in the process of hydrogen reduction of ex-g- $\mathrm{C}_{3} \mathrm{~N}_{4}-\mathrm{Ni}_{\mathrm{x}} \mathrm{O}_{\mathrm{y}}$ and next CVD in ethylene in the presence of reduced ex-g- $\mathrm{C}_{3} \mathrm{~N}_{4}-\mathrm{Ni}_{\mathrm{x}} \mathrm{O}_{\mathrm{y}}(\mathrm{CNT}-\mathrm{N}) \cdot \mathrm{g}-\mathrm{C}_{3} \mathrm{~N}_{4}$ and ex-g- $\mathrm{C}_{3} \mathrm{~N}_{4}$ (Figure $3 \mathrm{~A}, \mathrm{~B}$ ) exhibited aggregated morphology with irregular multiple-layered structures. The morphology of CNT-N (Figure 3C,D) is quite different from that of $g-C_{3} N_{4}$ and ex-g- $C_{3} N_{4}$. This sample is composed of nanotubular structures. Moreover, nickel residues which served as catalysts in nanotube growth were observed inside the tubes (green arrows in Figure 3D). The obtained nanotubes tend to agglomerate into larger clusters. The reference experiment without ethylene was also performed (Figure 4). This confirmed that ethylene is crucial in the process of nitrogen-doped carbon nanotube formation.

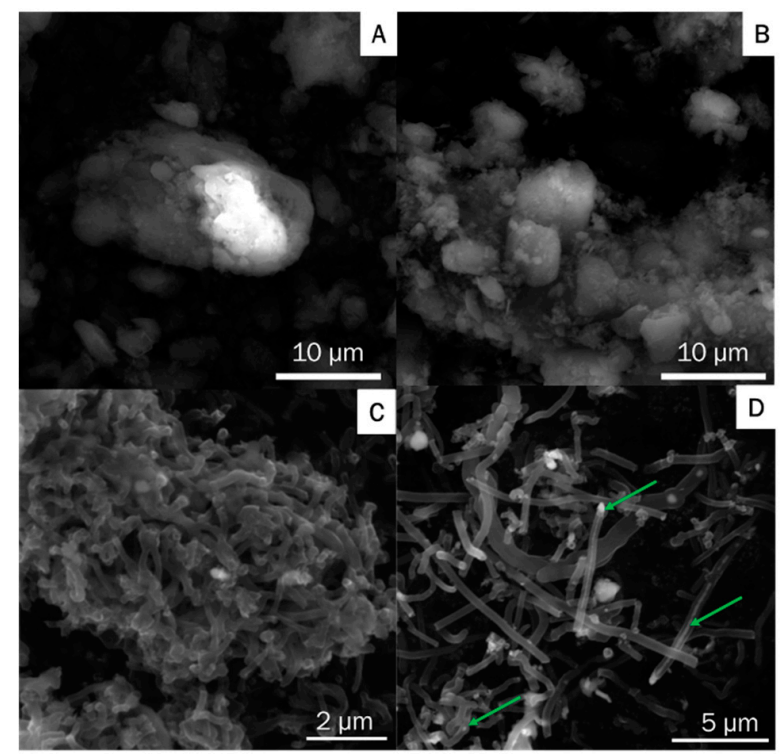

Figure 3. Scanning electron microscopy (SEM) images of (A) g- $\mathrm{C}_{3} \mathrm{~N}_{4},\left(\right.$ B) ex-g- $\mathrm{C}_{3} \mathrm{~N}_{4}$ and (C,D) CNT-N. 

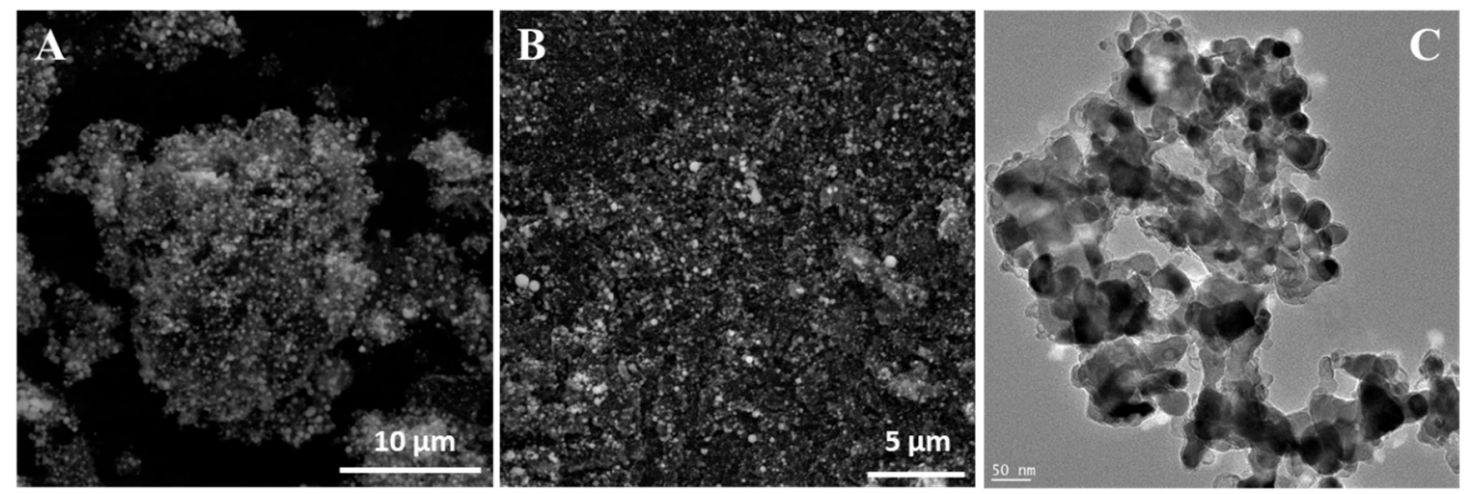

Figure 4. SEM $(\mathbf{A}, \mathbf{B})$ and TEM $(\mathbf{C})$ images of $\mathrm{g}-\mathrm{C}_{3} \mathrm{~N}_{4}-\mathrm{Ni}_{\mathrm{x}} \mathrm{O}_{\mathrm{y}}$ treated with hydrogen at $900{ }^{\circ} \mathrm{C}$.

To determine the role of ethylene during tube formation, an additional experiment was performed. In this step, $\mathrm{g}-\mathrm{C}_{3} \mathrm{~N}_{4}-\mathrm{Ni}_{\mathrm{x}} \mathrm{O}_{\mathrm{y}}$ was heated to $900{ }^{\circ} \mathrm{C}$ and then treated with hydrogen for $3 \mathrm{~h}$. In this case, the sample had not been exposed to ethylene. SEM and TEM images of the obtained product are presented in Figure 4. Here, tubular forms did not evolve. Additionally, metal particles agglomerated into larger clusters. A further experiment with $\mathrm{g}-\mathrm{C}_{3} \mathrm{~N}_{4}-\mathrm{Ni}_{\mathrm{x}} \mathrm{O}_{\mathrm{y}}$ treated only with ethylene (no hydrogen step) at $900{ }^{\circ} \mathrm{C}$ was conducted (Figure 5). It revealed that the obtained sample contained mostly onion-like particles. Some of these structures are formed on the surface of metal particles. Detailed TEM investigations revealed a few irregular, deformed tubular structures.
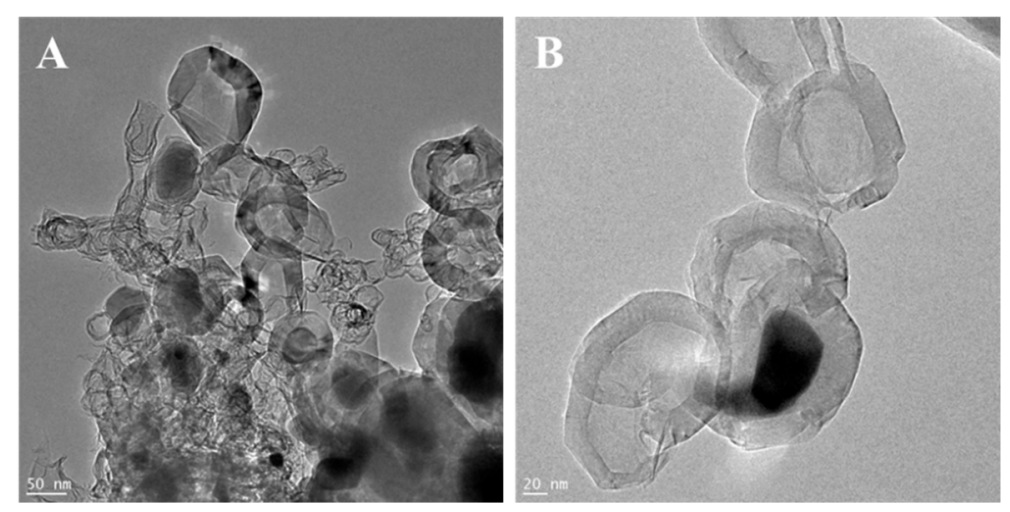

Figure 5. TEM $(\mathbf{A}, \mathbf{B})$ images of $\mathrm{g}-\mathrm{C}_{3} \mathrm{~N}_{4}-\mathrm{Ni}_{\mathrm{x}} \mathrm{O}_{\mathrm{y}}$ treated with ethylene at $900{ }^{\circ} \mathrm{C}$.

In order to study the morphology and elemental composition of CNT-N in greater detail, TEM, STEM and EDS analyses were performed (Figure 6). TEM images (Figure 6A,B) confirmed that the nanotubes have a diameter in the range of 200-300 nm. The elemental mapping (Figure 6D,E), carried out for the area marked as a white square on the STEM image (Figure 6C), revealed that carbon and nitrogen are the only elements present in the sample. Moreover, both components are homogeneously distributed in nanotubes. Furthermore, the line scan along the direction denoted by the red line in the STEM image (Figure 6G) was carried out and the obtained profiles are presented in Figure 6F. This analysis additionally confirms the chemical composition of CNT-N nanotubes. 

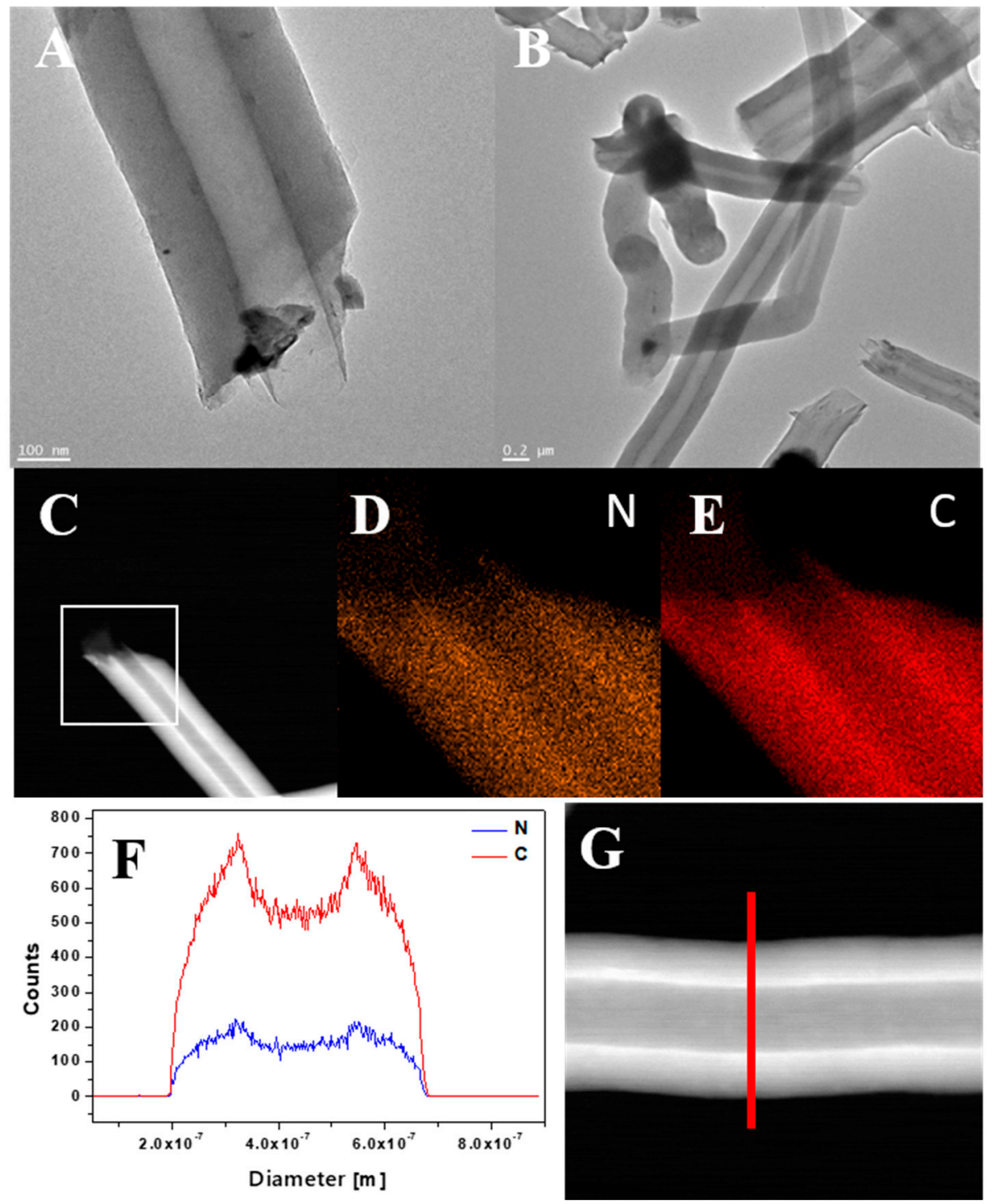

Figure 6. TEM images of CNT-N (A,B), STEM image of CNT-N (C) with corresponding mapping image of nitrogen (D) and carbon (E), and line profile (F) of CNT_N with corresponding STEM image (G).

Figure 7 presents HR-TEM and SAED images for $g-\mathrm{C}_{3} \mathrm{~N}_{4}$, ex-g- $\mathrm{C}_{3} \mathrm{~N}_{4}$, ex-g- $\mathrm{C}_{3} \mathrm{~N}_{4}-\mathrm{Ni}_{\mathrm{x}} \mathrm{O}_{\mathrm{y}}$ and CNT-N. For g- $\mathrm{C}_{3} \mathrm{~N}_{4}$ and ex-g- $\mathrm{C}_{3} \mathrm{~N}_{4}$ crystal fingers are not observed, which indicates that those products are amorphous, which is confirmed by SEAD analysis [35]. ex-g- $\mathrm{C}_{3} \mathrm{~N}_{4} \_\mathrm{Ni}_{\mathrm{x}} \mathrm{O}_{\mathrm{y}}$ and CNT_N exhibit SAED patterns typical for a polycrystalline structure. ex-g- $\mathrm{C}_{3} \mathrm{~N}_{4}-\mathrm{Ni}_{\mathrm{x}} \mathrm{O}_{\mathrm{y}}$ shows a few diffraction rings with discrete reflections corresponding to the different orientations of the single phase. The following rings have been characterized: (002) corresponding to nickel particles, (202) to $\mathrm{Ni}_{2} \mathrm{O}_{3}$, (110) to $\mathrm{NiO}_{2}$ and (110) to Ni. The pattern of copper (from TEM grid) can also be observed and is marked with (220). This analysis is in full agreement with the XRD analysis, which proved the presence of different nickel compounds in the sample. CNT-N exhibits three clear rings. The first two rings (111) and (200) are typical for nickel nanoparticles. Similar to the previous sample, the rings from copper can be detected. 


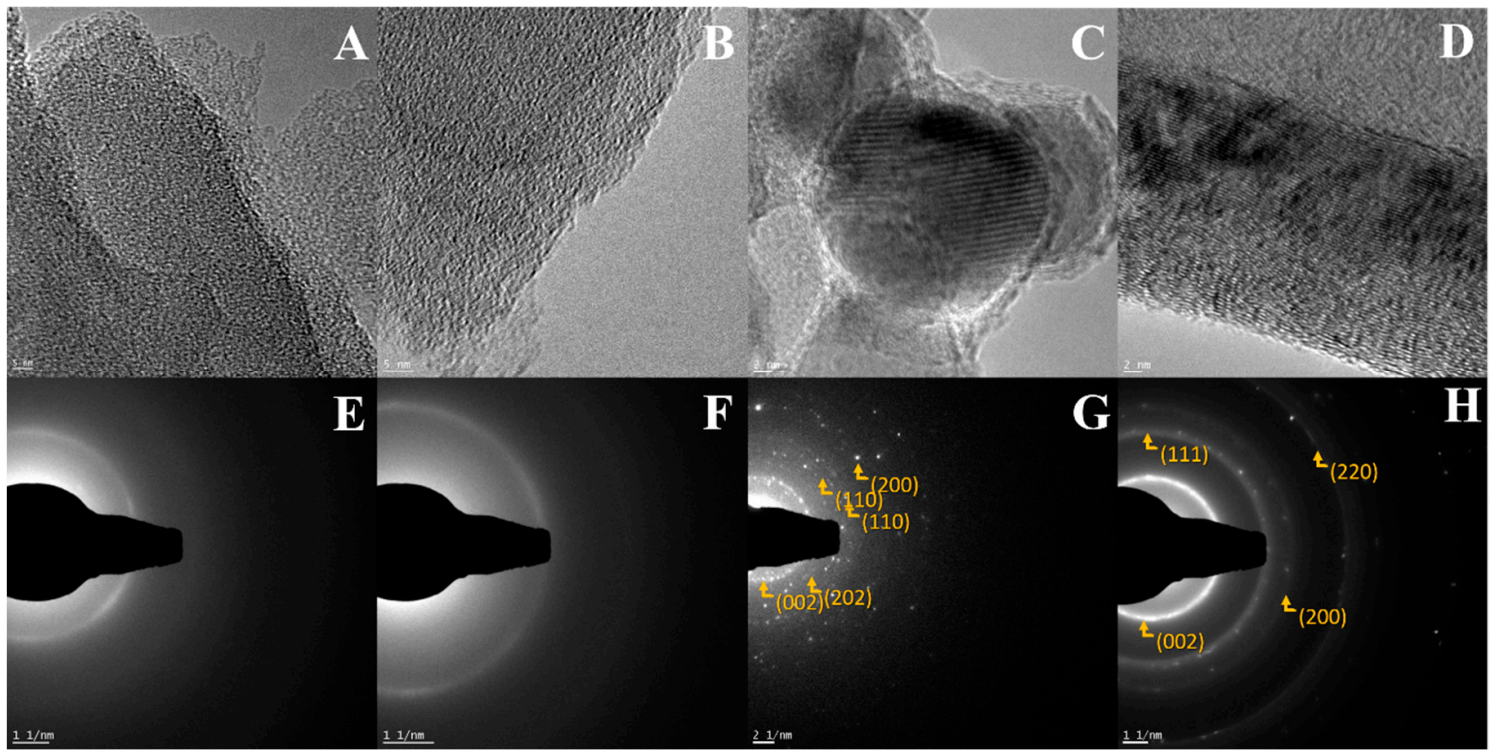

Figure 7. HR-TEM (A-D) and SAED (E-H) images of g- $\mathrm{C}_{3} \mathrm{~N}_{4}(\mathbf{A}, \mathbf{E})$, ex-g- $\mathrm{C}_{3} \mathrm{~N}_{4}(\mathbf{B}, \mathbf{F})$, ex-g- $\mathrm{C}_{3} \mathrm{~N}_{4}-\mathrm{Ni}_{\mathrm{x}} \mathrm{O}_{\mathrm{y}}$ $(\mathbf{C}, \mathbf{G})$ and CNT-N $(\mathbf{D}, \mathbf{H})$.

\subsection{Spectroscopic, Crystal and Thermogravimetric Studies}

XRD patterns of $\mathrm{g}-\mathrm{C}_{3} \mathrm{~N}_{4}$, ex-g- $\mathrm{C}_{3} \mathrm{~N}_{4}$, ex-g- $\mathrm{C}_{3} \mathrm{~N}_{4}-\mathrm{Ni}_{\mathrm{x}} \mathrm{O}_{\mathrm{y}}$ and CNT-N samples are shown in Figure 8. The peaks located at $13.1^{\circ}$ and $27.56^{\circ}$ can be observed for three samples $\left(\mathrm{g}-\mathrm{C}_{3} \mathrm{~N}_{4}\right.$, ex-g- $\mathrm{C}_{3} \mathrm{~N}_{4}$, ex-g- $\mathrm{C}_{3} \mathrm{~N}_{4}-\mathrm{Ni}_{\mathrm{x}} \mathrm{O}_{\mathrm{y}}$ ) and they are attributed to the presence of graphitic carbon nitride. Peaks at $13.1^{\circ}$ and $27.56^{\circ}$ correspond to the (100) and (002) crystalline phase, respectively (JCPDS 87-1526). Nickel-functionalized graphitic carbon nitride (ex-g- $\mathrm{C}_{3} \mathrm{~N}_{4}-\mathrm{Ni}_{\mathrm{x}} \mathrm{O}_{\mathrm{y}}$ ) exhibits the presence of different forms of a nickel compound. The diffraction peak at $2 \theta 44.8^{\circ}$ and $58.7^{\circ}$ is related to the nickel (III) oxide (JCPDS 14-0481), while two peaks at $\sim 39.4^{\circ}$ and $\sim 41.8^{\circ}$ belong to nickel (II) oxide (JCPDS 85-1977) [36,37]. During the last stage of CNT-N synthesis, nickel oxide is reduced to the metallic form of nickel and catalyzes the growth of nanotubes. This is confirmed by the disappearance of the peaks from $\mathrm{NiO}$ and $\mathrm{Ni}_{2} \mathrm{O}_{3}$ and the appearance of signals characteristic for the metallic form of nickel located at $\sim 44.5^{\circ}$ and $\sim 51.9^{\circ}$ (JCPDS 87-0712) [38]. Moreover, the diffraction peak at $26.2^{\circ}$ observed for CNT-N is assigned to the (002) plane of graphitic carbon.

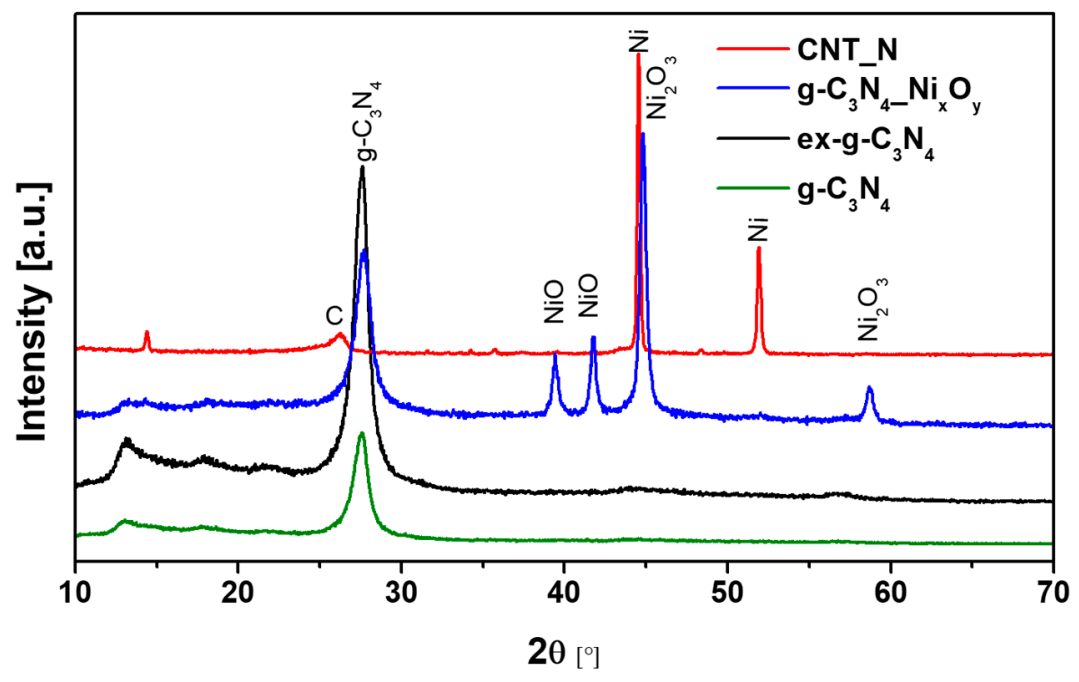

Figure 8. XRD patterns of $g-\mathrm{C}_{3} \mathrm{~N}_{4}$, ex-g- $\mathrm{C}_{3} \mathrm{~N}_{4}$, ex-g- $\mathrm{C}_{3} \mathrm{~N}_{4}-\mathrm{Ni}_{\mathrm{x}} \mathrm{O}_{\mathrm{y}}$ and CNT-N. 
Thermogravimetric analysis was carried out in order to determine the thermal properties of the samples. Figure 9 represents the TG (a) and DTG (b) curves of g- $\mathrm{C}_{3} \mathrm{~N}_{4}$, ex-g- $\mathrm{C}_{3} \mathrm{~N}_{4}$, ex-g- $\mathrm{C}_{3} \mathrm{~N}_{4}-\mathrm{Ni}_{\mathrm{x}} \mathrm{O}_{\mathrm{y}}$ and CNT-N heat-treated under air flow. Here, the exfoliation process does not affect the thermal stability of graphitic carbon nitride. For both $\mathrm{g}-\mathrm{C}_{3} \mathrm{~N}_{4}$ and ex-g- $\mathrm{C}_{3} \mathrm{~N}_{4}$, the degradation process starts at about $500{ }^{\circ} \mathrm{C}$ and continues until complete decomposition. Functionalization with nickel oxides (ex-g- $\mathrm{C}_{3} \mathrm{~N}_{4}$-NixOy) significantly decreased the decomposition temperature to $350{ }^{\circ} \mathrm{C}$. The residue mass after the analysis is $\sim 28.7 \mathrm{wt} \%$ and this value is assigned to the amount of nickel compounds in the sample. Two steps can be distinguished on the TGA curve obtained for the CNT-N sample. The first one begins at a temperature of $468^{\circ} \mathrm{C}$ and is attributed to the removal of more defected carbon structures. The second one, from a temperature of $565{ }^{\circ} \mathrm{C}$, is related to the degradation of carbon nanotubes. The residual mass is $\sim 24.8 \mathrm{wt} \%$ which is the nickel compounds content in the sample.
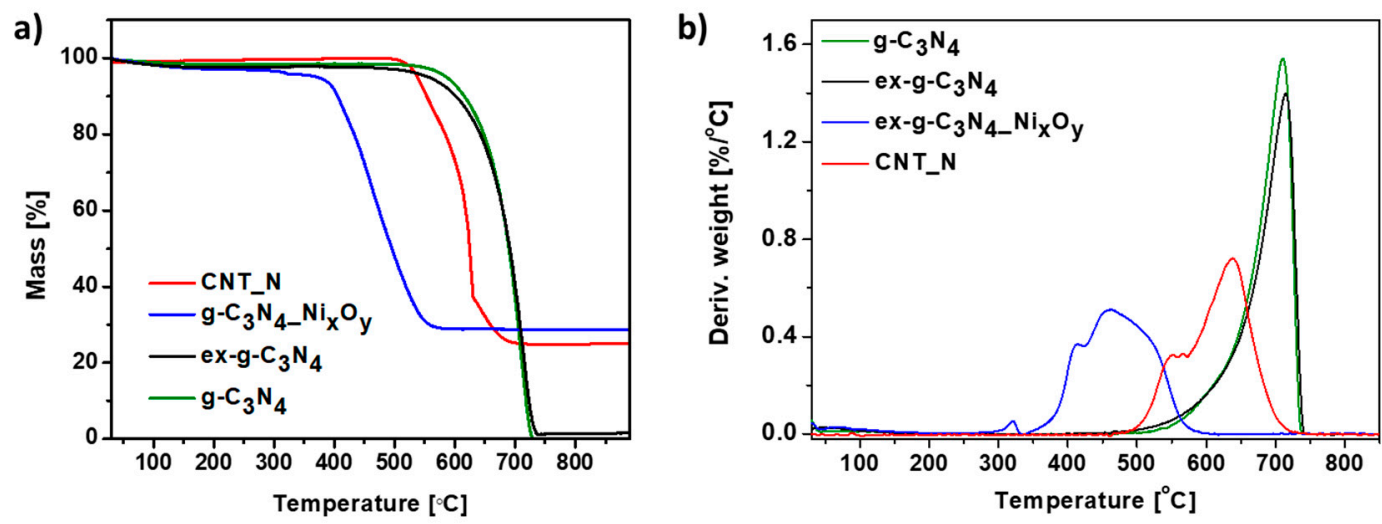

Figure 9. Thermogravimetric (a) and derivative thermogravimetric curves (b) of $g-C_{3} N_{4}, e x-g-C_{3} N_{4}$, ex-g- $\mathrm{C}_{3} \mathrm{~N}_{4}-\mathrm{Ni}_{\mathrm{x}} \mathrm{O}_{\mathrm{y}}$ and CNT-N conducted in air.

Additionally, TGA analysis performed in argon atmosphere was conducted. Thermogravimetric (TG) (Figure 9a) and derivative thermogravimetric (DTG) (Figure 9b) curves of g- $\mathrm{C}_{3} \mathrm{~N}_{4}$, ex-g- $\mathrm{C}_{3} \mathrm{~N}_{4}$, ex-g- $\mathrm{C}_{3} \mathrm{~N}_{4}-\mathrm{Ni}_{\mathrm{x}} \mathrm{O}_{\mathrm{y}}$ and CNT-N heat-treated under argon flow are presented in Figure 10. $\mathrm{g}_{-} \mathrm{C}_{3} \mathrm{~N}_{4}$ and ex-g- $\mathrm{C}_{3} \mathrm{~N}_{4}$ are stable up to $\sim 500{ }^{\circ} \mathrm{C}$, either in air or argon atmosphere (see Figures 9 and 10). This means that both g- $\mathrm{C}_{3} \mathrm{~N}_{4}$ and ex-g- $\mathrm{C}_{3} \mathrm{~N}_{4}$ can endure high temperatures, even in an oxidizing atmosphere. The weight loss at above $500{ }^{\circ} \mathrm{C}$ is not due to the oxidation by $\mathrm{O}_{2}$, but to the direct thermal decomposition of $\mathrm{g}-\mathrm{C}_{3} \mathrm{~N}_{4}$ itself [39]. Moreover, the residual mass of $\sim 3 \mathrm{wt} \%$ is observed in an inert atmosphere. ex-g- $\mathrm{C}_{3} \mathrm{~N}_{4}$-NixOy exhibited different thermal stability in air and argon atmosphere, which was higher in Ar flow. Furthermore, the residual mass after analysis is $\sim 34 \mathrm{wt} \%(\sim 24.8 \mathrm{wt} \%$ in air). The obtained CNT-N is stable in argon atmosphere.
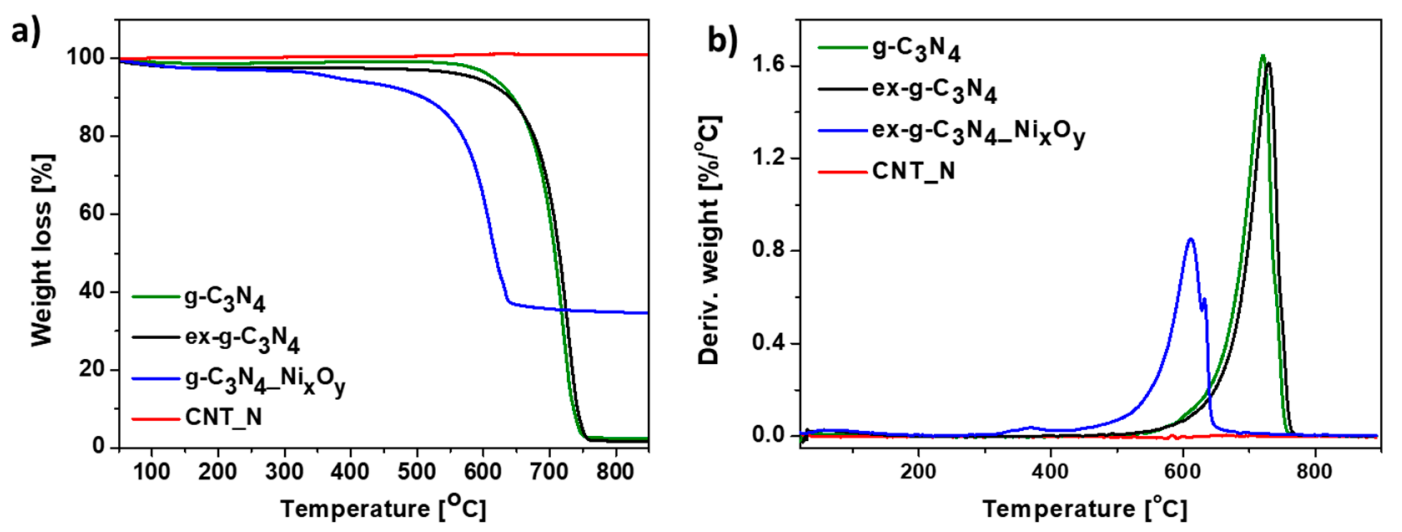

Figure 10. Thermogravimetric (a) and derivative thermogravimetric (b) curves of $g-C_{3} N_{4}$, ex-g- $C_{3} N_{4}$, ex-g- $\mathrm{C}_{3} \mathrm{~N}_{4}-\mathrm{Ni}_{\mathrm{x}} \mathrm{O}_{\mathrm{y}}$ and CNT-N conducted in Ar. 
Raman spectroscopy was introduced to provide information about the chemical structures of g- $\mathrm{C}_{3} \mathrm{~N}_{4}$, ex-g- $\mathrm{C}_{3} \mathrm{~N}_{4}$ and CNT-N (Figure 11). Raman spectra of g- $\mathrm{C}_{3} \mathrm{~N}_{4}$ and ex-g- $\mathrm{C}_{3} \mathrm{~N}_{4}$ contain several bands observed in the range of $700-1630 \mathrm{~cm}^{-1}$ which are attributed to graphitic carbon nitride [40-42]. Additionally, the vibrations at 753,977, 1120,1156, 1236 and $1314 \mathrm{~cm}^{-1}$ are assigned to the stretching vibration of aromatic C-N heterocycle characteristic to melem. [43,44] The peaks at $700-1000 \mathrm{~cm}^{-1}$ are related to the different types of ring breathing modes of s-triazine. The Raman response of the tubular sample exhibits $\mathrm{D}\left(1318 \mathrm{~cm}^{-1}\right), \mathrm{G}\left(1580 \mathrm{~cm}^{-1}\right)$ and $2 \mathrm{D}\left(2700 \mathrm{~cm}^{-1}\right)$ bands what confirm the formation of graphitic carbon structure in the sample $[45,46]$.

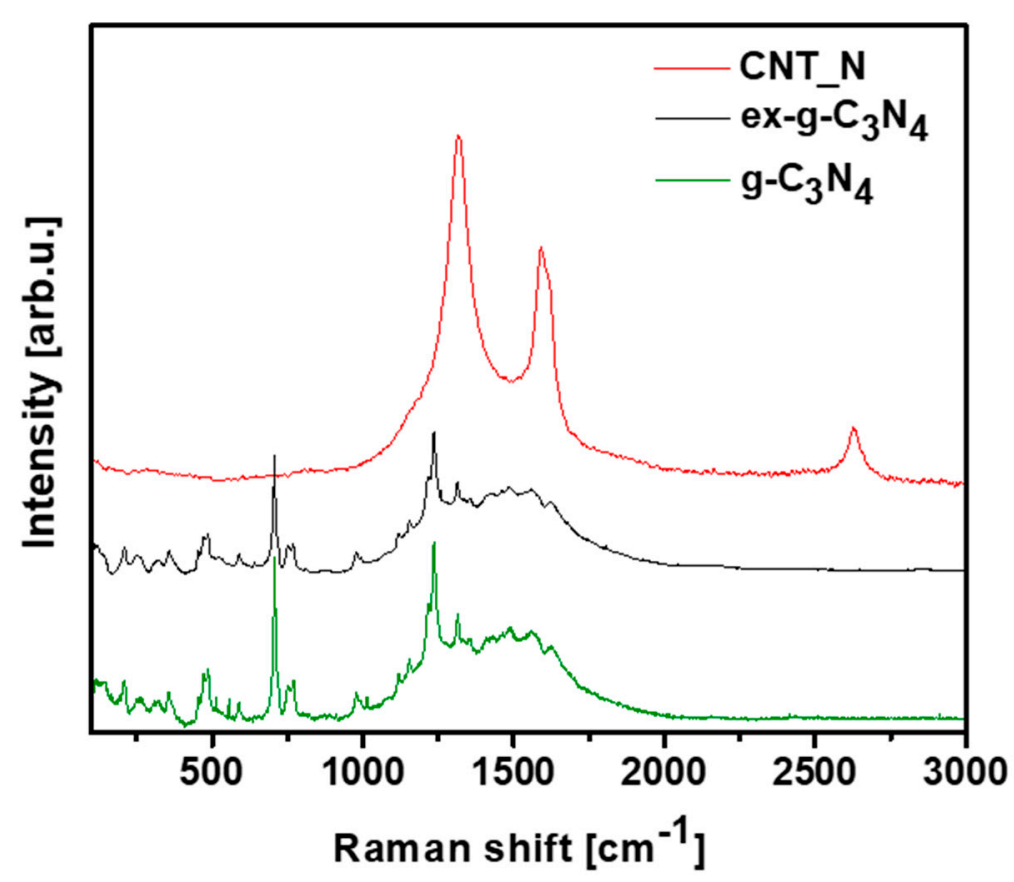

Figure 11. Raman spectra of g- $\mathrm{C}_{3} \mathrm{~N}_{4}$, ex-g- $\mathrm{C}_{3} \mathrm{~N}_{4}$ and CNT-N.

\subsection{Mechanism of the CNT-N Formation}

All the performed experiments clearly indicate that the metallic nickel serves as an active catalyst for the formation of the nanotubes. To verify this, the additional experiments in which g- $\mathrm{C}_{3} \mathrm{~N}_{4}-\mathrm{Ni}_{\mathrm{x}} \mathrm{O}_{\mathrm{y}}$ were treated with hydrogen or ethylene at $900{ }^{\circ} \mathrm{C}$ were performed (see Figures 4 and 5). The tubular forms did not evolve when $\mathrm{g}-\mathrm{C}_{3} \mathrm{~N}_{4}-\mathrm{Ni}_{\mathrm{x}} \mathrm{O}_{\mathrm{y}}$ was treated only with $\mathrm{H}_{2}$. Moreover, treating of g- $\mathrm{C}_{3} \mathrm{~N}_{4}-\mathrm{Ni}_{\mathrm{x}} \mathrm{O}_{\mathrm{y}}$ only with ethylene (no hydrogen step) at $900{ }^{\circ} \mathrm{C}$ results in the formation of cocktail of carbon onion-like structures or short irregular tube-like structures. Therefore, the key step was the reduction of nickel oxides to metallic nickel in the hydrogen/ethylene flow. This was also confirmed by XRD studies (see Figure 4). In the next step, carbon and nitrogen from $g-\mathrm{C}_{3} \mathrm{~N}_{4}$ diffused into nickel particles and when the oversaturation was reached these elements started to grow in the form of tubes. The elemental and the structural properties of the tubes were confirmed in EDX analysis and the Raman response of the sample. The whole process of the tubes formation is presented schematically in Figure 12. 


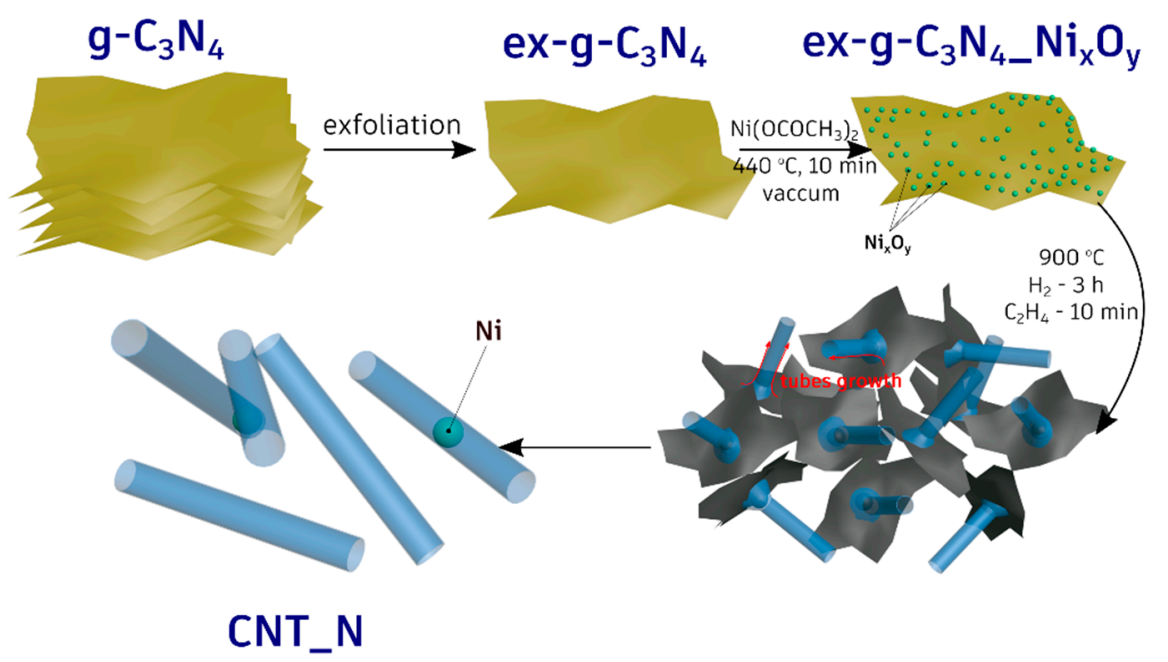

Figure 12. Schematic diagram of N-doped carbon nanotubes synthesis.

\section{Conclusions}

In summary, we present a simple and effective method for the synthesis of $\mathrm{N}$-doped carbon nanotubes with a diameter in the range of $200-300 \mathrm{~nm}$. CNT-N were produced in the reaction of chemical vapor deposition in the presence of ethylene flow. Here, exfoliated graphitic carbon nitride functionalized with nickel oxides has been used as a starting material in CNT-N formation. This material plays a double role: (1) nickel was a catalyst in nanotube growth and (2) graphitic carbon nitride served as support for nickel nanoparticles and as carbon/nitrogen source. The results also prove that ethylene plays a crucial role in the formation of tubes. On one side, it carboreduced the nickel oxide (II) to metallic nickel which was an active phase in the growth of the nanotubes, and, on the other hand, it was a source of carbon in the final sample. The obtained N-doped nanotubes may show promising performance in a variety of applications such as catalysis, lithium-ion batteries, supercapacitors and so on.

Author Contributions: Conceptualization, E.M. and B.Z.; Funding acquisition, E.M.; Investigation, K.M. and B.Z.; writing—original draft preparation, K.M., B.Z. and E.M., writing—review and editing, K.M., B.Z. and E.M.; supervision, E.M. and R.J.K. All authors have read and agreed to the published version of the manuscript.

Funding: This study was funded by National Science Centre, Poland (grant number 2015/19/B/ST8/00648).

Conflicts of Interest: The authors declare that they have no conflict of interest.

\section{References}

1. Mozetič, M. Surface Modification to Improve Properties of Materials. Materials 2019, 12, 441. [CrossRef] [PubMed]

2. Kalia, S.; Boufi, S.; Celli, A. Nanofibrillated cellulose: Surface modification and potential applications. Colloid Polym. Sci. 2014, 292, 5-31. [CrossRef]

3. Figueiredo, J.L.; Pereira, M.F.R.; Freitas, M.M.A.; Órfão, J.J.M. Modification of the surface chemistry of activated carbons. Carbon 1999, 37, 1379-1389. [CrossRef]

4. Kukulka, W.; Cendrowski, K.; Mijowska, E. Electrochemical performance of MOF-5 derived carbon nanocomposites with 1D, 2D and 3D carbon structures. Electrochem. Acta 2019, 307, 582-594. [CrossRef]

5. Zhou, Q.; Li, L.; Xin, Z.; Yu, Y.; Wang, L.; Zhang, W. Visible light response and heterostructure of composite CdS@ZnS-ZnO to enhance its photocatalytic activity. J. Alloys Compd. 2020, 813, 152190. [CrossRef]

6. Wu, Y.; He, Y.; Chen, C.; Li, H.; Xia, Y.; Zhou, T. MoS $2-C N F s$ composites to enhance the anticorrosive and mechanical performance of epoxy coating. Prog. Org. Coat. 2019, 129, 178-186. [CrossRef]

7. Biju, V. Chemical modifications and bioconjugate reactions of nanomaterials for sensing, imaging, drug delivery and therapy. Chem. Soc. Rev. 2014, 43, 744-764. [CrossRef] 
8. Bhatnagar, A.; Hogland, W.; Marques, M.; Sillanpää, M. An overview of the modification methods of activated carbon for its water treatment applications. Chem. Eng. J. 2019, 219, 499-511. [CrossRef]

9. Wang, S.; Sun, H.; Ang, H.M.; Tadé, M.O. Adsorptive remediation of environmental pollutants using novel graphene-based nanomaterials. Chem. Eng. J. 2013, 226, 336-347. [CrossRef]

10. Li, H.F.; Wu, F.; Wang, C.; Zhang, P.X.; Hu, H.Y.; Xie, N.; Pan, M.; Zeng, Z.; Deng, S.; Wu, M.H.; et al. One-Step Chemical Vapor Deposition Synthesis of 3D N-doped Carbon Nanotube/N-doped Graphene Hybrid Material on Nickel Foam. Nanomaterials 2018, 8, 700. [CrossRef]

11. Tian, W.; Zhang, H.; Sun, H.; Suvorova, A.; Saunders, M.; Tade, M.; Wang, S. Heteroatom (N or N-S)-Doping Induced Layered and Honeycomb Microstructures of Porous Carbons for $\mathrm{CO}_{2}$ Capture and Energy Applications. Adv. Funct. Mater. 2016, 26, 8651-8661. [CrossRef]

12. Liu, J.; Shen, A.; Wei, X.; Zhou, K.; Chen, W.; Chen, F.; Xu, J.; Wang, S.; Dai, L. Ultrathin Wrinkled N Doped Carbon Nanotubes for Noble-Metal Loading and Oxygen Reduction Reaction. ACS Appl. Mater. Interfaces 2015, 7, 20507-20512. [CrossRef] [PubMed]

13. Yang, L.; Shui, J.; Du, L.; Shao, Y.; Liu, J.; Dai, L.; Hu, Z. Carbon-Based Metal-Free ORR Electrocatalysts for Fuel Cells: Past, Present, and Future. Adv. Mater. 2019, 31, 1804799. [CrossRef] [PubMed]

14. Paraknowitsch, J.P.; Thomas, A. Doping carbons beyond nitrogen: An overview of advanced heteroatom doped carbons with boron, sulphur and phosphorus for energy applications. Energy Environ. Sci. 2013, 6, 2839-2855. [CrossRef]

15. Hao, J.; Yang, W.; Peng, Z.; Zhang, C.; Huang, Z.; Shi, W. A Nitrogen Doping Method for CoS 2 Electrocatalysts with Enhanced Water Oxidation Performance. ACS Catal. 2017, 7, 4214-4220. [CrossRef]

16. Chen, H.; Wei, Y.; Wang, J.; Qiao, W.; Ling, L.; Long, D. Controllable Nitrogen Doping of High-Surface-Area Microporous Carbons Synthesized from an Organic-Inorganic Sol-Gel Approach for Li-S Cathodes. ACS Appl. Mater. Interfaces 2015, 7, 21188-21197. [CrossRef]

17. Ariharan, A.; Viswanathan, B.; Nandhakumar, W. Nitrogen-incorporated carbon nanotube derived from polystyrene and polypyrrole as hydrogen storage material. Int. J. Hydrogen Energy 2018, 43, 5077-5088. [CrossRef]

18. Wang, Y.; Yao, L.; Liu, X.; Chen, J.; Liu, W.; Liu, T.; Sun, M.; Zhao, L.; Ding, F.; Lu, Z.; et al. $\mathrm{CuCo}_{2} \mathrm{O}_{4} / \mathrm{N}_{-}$Doped CNTs loaded with molecularly imprinted polymer for electrochemical sensor: Preparation, characterization and detection of metronidazole. Biosens. Bioelectron. 2019, 142, 111483. [CrossRef]

19. Zhang, P.; Wei, J.-S.; Chen, X.-B.; Xiong, H.-M. Heteroatom-doped carbon dots based catalysts for oxygen reduction reactions. J. Colloid Interface Sci. 2019, 537, 716-724. [CrossRef]

20. Zhu, X.; Li, Y.; Li, R.; Tu, K.; Li, J.; Xie, Z.; Lei, J.; Liu, D.; Qu, D. Self-assembled N-doped carbon with a tube-in-tube nanostructure for lithium-sulfur batteries. J. Colloid Interface Sci. 2020, 559, 224-253. [CrossRef]

21. Chiang, Y.-C.; Hsu, W.-L.; Lin, S.-Y.; Juang, R.-S. Enhanced $\mathrm{CO}_{2}$ adsorption on activated carbon fibers grafted with nitrogen-doped carbon nanotubes. Materials 2017, 10, 511. [CrossRef] [PubMed]

22. Adjizian, L.-L.; Leghrib, R.; Koos, A.A.; Suarez-Martinez, I.; Crossley, A.; Wagner, P.; Grobert, N.; Llobet, E.; Ewels, C.P. Boron- and nitrogen-doped multi-wall carbon nanotubes for gas detection. Carbon 2014, 66, 662-673. [CrossRef]

23. Wu, J.; Pan, Z.; Zhang, Y.; Wang, B.; Peng, H. The recent progress of nitrogen-doped carbon nanomaterials for electrochemical batteries. J. Mater. Chem. A 2018, 6, 12932-12944. [CrossRef]

24. Liu, Q.; Zeng, C.; Xie, Z.; Ai, L.; Liu, Y.; Zhou, Q.; Jiang, J.; Sun, H.; Wang, S. Cobalt@nitrogen-doped bamboo-structured carbon nanotube to boost photocatalytic hydrogen evolution on carbon nitride. Appl. Catal. B Environ. 2019, 254, 443-451. [CrossRef]

25. Liu, Q.; Pu, Z.; Asiri, A.M.; Sun, X. Bamboo-like nitrogen-doped carbon nanotubes toward fluorescence recovery assay for DNA detection. Sens. Actuators B Chem. 2015, 206, 37-42. [CrossRef]

26. Yao, Y.; Chen, H.; Lian, C.; Wei, F.; Zhang, D.; Wu, G.; Chen, B.; Wang, S. Fe, Co, Ni nanocrystals encapsulated in nitrogen-doped carbon nanotubes as Fenton-like catalysts for organic pollutant removal. J. Hazard. Mater. 2016, 314, 129-139. [CrossRef]

27. Chen, Z.; Higgins, D.; Chen, Z. Nitrogen doped carbon nanotubes and their impact on the oxygen reduction reaction in fuel cells. Carbon 2010, 48, 3057-3065. [CrossRef]

28. Nxumalo, E.N.; Nyamori, V.O.; Coville, N.J. CVD synthesis of nitrogen doped carbon nanotubes using ferrocene/aniline mixtures. J. Organomet. Chem. 2008, 693, 2942-2948. [CrossRef] 
29. Xiong, W.; Wang, Y.; He, S.; Hao, F.; Yang, Y.; Lv, Y.; Zhang, W.; Liu, P.; Luo, H. Nitrogen-doped carbon nanotubes as a highly active metal-free catalyst for nitrobenzene hydrogenation. Appl. Catal. B Environ. 2020, 260, 118105. [CrossRef]

30. Tang, C.; Bando, Y.; Golberg, D.; Xu, F. Structure and nitrogen incorporation of carbon nanotubes synthesized by catalytic pyrolysis of dimethylformamide. Carbon 2004, 42, 2625-2633. [CrossRef]

31. Chetty, R.; Kundu, S.; Xia, W.; Bron, M.; Schuhmann, W.; Chirila, V.; Brandl, W.; Reincecke, T.; Muhler, M. PtRu nanoparticles supported on nitrogen-doped multiwalled carbon nanotubes as catalyst for methanol electrooxidation. Electrochim. Acta 2009, 54, 4208-4215. [CrossRef]

32. Kumar, M. Carbon Nanotube Synthesis and Growth Mechanism. In Carbon Nanotubes-Synthesis, Characterization, Applications; Web of science: Philadelphia, PA, USA, 2011; pp. 147-170. ISBN 978-953-307-497-9.

33. Shukrullah, S.; Naz, M.Y.; Mohamed, N.M.; Ibrahim, K.A.; Abdel-Salam, N.M.; Ghaffar, A. CVD Synthesis, Functionalization and $\mathrm{CO}_{2}$ Adsorption Attributes of Multiwalled Carbon Nanotubes. Processes 2019, 7, 634. [CrossRef]

34. Manawi, Y.M.; Samara, A.; Al-Ansari, T.; Atieh, M.A. A Review of Carbon Nanomaterials' Synthesis via the Chemical Vapor Deposition (CVD) Method. Materials 2018, 11, 822. [CrossRef] [PubMed]

35. Zhang, Y.; Pan, Q.; Chai, G.; Liang, M.; Dong, G.; Zhang, Q.; Qiu, J. Synthesis and luminescence mechanism of multicolor-emitting g-C3N4 nanopowders by low temperature thermal condensation of melamine. Sci. Rep. 2013, 3, 1943. [CrossRef]

36. Day, S.; Bhattacharjee, S.; Chaudhuri, M.G.; Bose, R.S.; Halder, S.; Ghosh, C.K. Synthesis of pure nickel(III) oxide nanoparticles at room temperature for $\mathrm{Cr}(\mathrm{VI})$ ion removal. RSC Adv. 2015, 5, 54717-54726. [CrossRef]

37. Rifaya, M.N.; Theivasanthi, T.; Alagar, M. Chemical Capping Synthesis of Nickel Oxide Nanoparticles and their Characterizations Studies. Nanosci. Nanotechnol. 2012, 5, 134-138. [CrossRef]

38. Arghavanian, R.; Bostani, B.; Parvini-Ahmadi, N. Characterisation of coelectrodeposited Ni-Al composite coating. Surf. Eng. 2015, 31, 189-193. [CrossRef]

39. Zhu, J.; Xiao, P.; Li, H.; Carabineiro, S.A.C. Graphitic Carbon Nitride: Synthesis, Properties, and Applications in Catalysis. ACS Appl. Mater. Interfaces 2014, 6, 16449-16465. [CrossRef]

40. Zhang, M.; Bai, X.; Liu, D.; Wang, J.; Zhu, Y. Enhanced catalytic activity of potassium-doped graphitic carbon nitride induced by lower valence position. Appl. Catal. B Environ. 2015, 164, 77-81. [CrossRef]

41. Wang, Y.Y.; Yang, W.J.; Chen, X.J.; Wang, J.; Zhu, Y.F. Photocatalytic activity enhancement of core-shell structure g- $\mathrm{C}_{3} \mathrm{~N}_{4} @ \mathrm{TiO}_{2}$ via controlled ultrathin g- $\mathrm{C}_{3} \mathrm{~N}_{4}$ layer. Appl. Catal. B Environ. 2018, 220, 337-347. [CrossRef]

42. Tonda, S.; Kumar, S.; Kandula, S.; Shanker, V. Fe-doped and -mediated graphitic carbon nitride nanosheets for enhanced photocatalytic performance under natural sunlight. J. Mater. Chem. A 2014, 2, 6772-6780. [CrossRef]

43. Hu, S.W.; Yang, L.W.; Tian, Y.; Wei, X.L.; Ding, J.W.; Zhong, J.X.; Chu, P.K. Simultaneous nanostructure and heterojunction engineering of graphitic carbon nitride via in situ Ag doping for enhanced photoelectrochemical activity. Appl. Catal. B Environ. 2015, 163, 611-622. [CrossRef]

44. Liu, S.; Ke, J.; Sun, H.; Liu, J.; Tade, M.O.; Wang, S. Size dependence of uniformed carbon spheres in promoting graphitic carbon nitride toward enhanced photocatalysis. Appl. Catal. B Environ. 2017, 204, 358-364. [CrossRef]

45. Giannakopoulou, T.; Papailias, I.; Todorova, N.; Boukos, N.; Liu, Y.; Yu, J.G.; Trapalis, C. Tailoring the energy band gap and edges' potentials of $\mathrm{g}-\mathrm{C}_{3} \mathrm{~N}_{4} / \mathrm{TiO}_{2}$ composite photocatalysts for NOx removal. Chem. Eng. J. 2017, 310, 571-580. [CrossRef]

46. Zinin, P.V.; Ming, L.C.; Sharma, S.K.; Khabashesku, V.N.; Liu, X.; Hong, S.; Endo, S.; Acosta, T. Ultraviolet and near-infrared Raman spectroscopy of graphitic $\mathrm{C}_{3} \mathrm{~N}_{4}$ phase. Chem. Phys. Lett. 2009, 472, 69-73. [CrossRef]

(C) 2020 by the authors. Licensee MDPI, Basel, Switzerland. This article is an open access article distributed under the terms and conditions of the Creative Commons Attribution (CC BY) license (http://creativecommons.org/licenses/by/4.0/). 